PALEO

Revue d'archéologie préhistorique

$26 \mid 2015$

Varia

New discoveries of portable art in the Magdalenian of Bourrouilla Cave (Arancou, PyrénéesAtlantiques, France)

Nouvelles découvertes d'art mobilier dans le Magdalénien de Bourrouilla

(Arancou, Pyrénées-Atlantiques, France)

Frédéric Plassard, Lise Aurière, François-Xavier Chauvière, Carole Fritz et Morgane Dachary

(2) OpenEdition

Journals

Édition électronique

URL : http://journals.openedition.org/paleo/3037

DOI : $10.4000 /$ paleo.3037

ISSN : 2101-0420

Éditeur

SAMRA

Édition imprimée

Date de publication : 1 décembre 2015

Pagination : 215-224

ISSN : $1145-3370$

Référence électronique

Frédéric Plassard, Lise Aurière, François-Xavier Chauvière, Carole Fritz et Morgane Dachary, « New discoveries of portable art in the Magdalenian of Bourrouilla Cave (Arancou, Pyrénées-Atlantiques, France) », PALEO [En ligne], 26 | 2015, mis en ligne le 26 avril 2016, consulté le 07 juillet 2020. URL : http://journals.openedition.org/paleo/3037 ; DOI : https://doi.org/10.4000/paleo.3037

Ce document a été généré automatiquement le 7 juillet 2020.

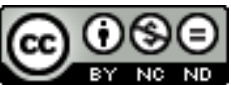

PALEO est mis à disposition selon les termes de la licence Creative Commons Attribution - Pas d'Utilisation Commerciale - Pas de Modification 4.0 International 


\title{
New discoveries of portable art in the Magdalenian of Bourrouilla Cave (Arancou, Pyrénées-Atlantiques, France)
}

\author{
Nouvelles découvertes d'art mobilier dans le Magdalénien de Bourrouilla \\ (Arancou, Pyrénées-Atlantiques, France)
}

Frédéric Plassard, Lise Aurière, François-Xavier Chauvière, Carole Fritz et Morgane Dachary

We wish to thank Stéphane Madelaine and Clément Birouste for the anatomic and specific determinations of the remains. The restoration-consolidation of the objects was conducted by $M$. Boucharat and funded by the Ministry of Culture (SRA Aquitaine), to whom we express our sincere thanks.

\section{Introduction}

1 The excavations conducted in Bourrouilla Cave at Arancou since 1998 led to the discovery of a number of portable art remains which are clearly part of the Upper Magdalenian (Aurière et al. 2013; Dachary et al. in press). These discoveries complete the corpus from clandestine excavation spoil heaps, recording site occupation at the end of the Middle Magdalenian (Chauchat et al. 1999; Fritz and Roussot in Chauchat et al. 1999). New evidence of symbolic Magdalenian behaviour was discovered during the 2014 excavation campaign. The archaeological context of these remains was published recently (Dachary et al. in press), without a detailed description of the art works. This was due to the high fragmentation rate of the pieces at the time of discovery, necessitating restoration and consolidation work before any detailed study could be carried out (fig.1). This work has now been completed and the pieces can now be 
documented with descriptions of the decorations. This short paper presents these pieces.

2 Seven of the eight objects described below are from SU 2007E, a stratigraphic subdivision clearly attributed to the Upper Magdalenian and described elsewhere (Dachary et al. in press). The last object, a half-round rod from SU 2010, underlying SU 2007F, contributes to the debate regarding the chronological attribution of this SU and more generally to the discussion on the transition between the Middle and Upper Magdalenian at Arancou.

3 The chosen blank types, the iconography and the degree of technical mastery provide new insights and clarify some of the observations relating to the pieces known up until now.

Figure 1 - a - ARA14 L18 1010. Fragment of a bovine scapula decorated with transverse engravings. b - ARA13 L17 4826. Another fragment from the same (?) object. c - ARA14 L18 1010 before restoration (Photo F. Plassard).

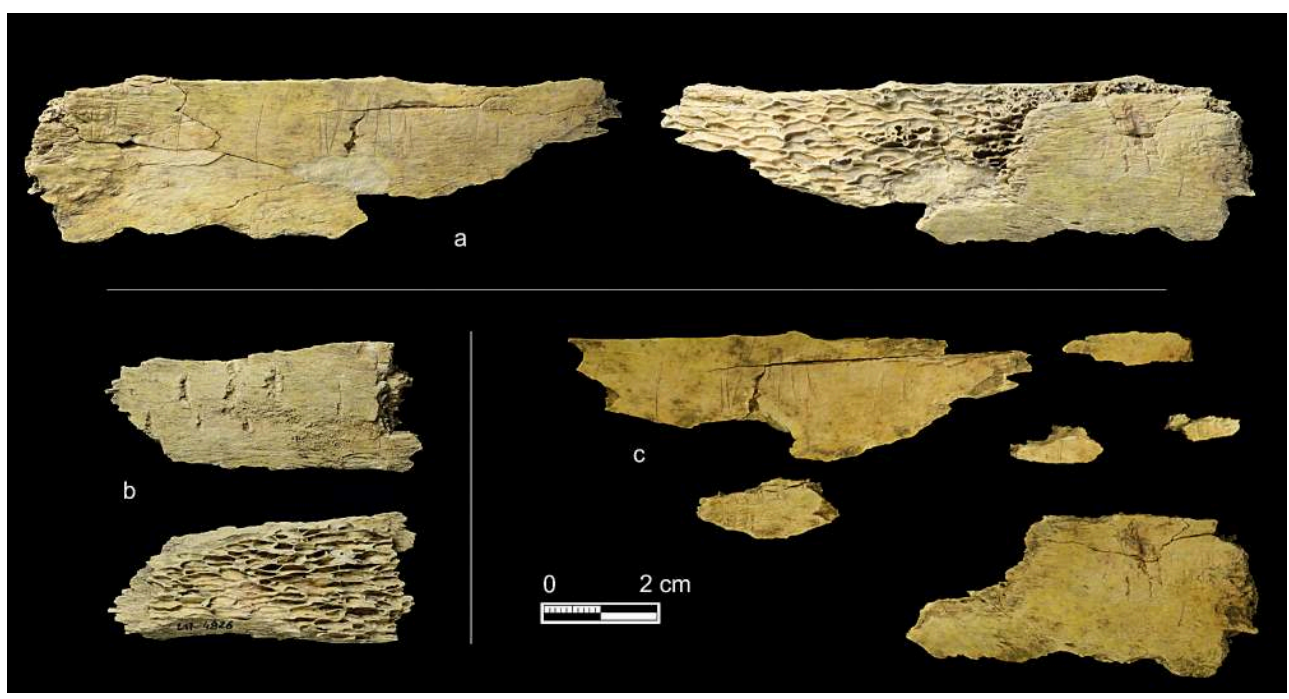

\section{1 - Fragment of an engraved scapula with non- figurative decoration (ARA14 L18 1010 and ARA13 L17 4826)}

Dim.: $92 \times 29 \times 10 \mathrm{~mm}$ and $41 \times 21 \times 6 \mathrm{~mm}$

4 The object L18 1010 was discovered in nine fragments during the 2014 campaign (fig. 1c) and was studied after restoration. It presents very marked similarities (morphology, surface state and anthropogenic marks) with another remain discovered in 2013: L17 4826 (fig. 1b). No physical connection was made between these two objects but we can consider that they are fragments of the same object. It appears to be a fragment of a right scapula from a large bovine.

5 The best preserved surface of the large fragment (L18 1010) bears about twenty fairly parallel lines organized perpendicularly to the axis of the piece (fig. 1a).

6 The second surface is only conserved over a limited surface for L18 1010, but L17 4826 presents an equivalent conserved cortical surface. The observable marks are related to denting and plucking actions rather than to engraving. They are fairly short wide 
marks, sometimes with slightly bulging edges that are difficult to interpret: they may represent taphonomic alterations, carnivore marks or use as a retoucher in spite of the fragility of this anatomic element?

\section{2 - Engraved matrix of interlocked chevrons (ARA14 R2014-304)}

Dim.: 187 x 29 x $13 \mathrm{~mm}$

7 At the time of discovery, this remain was made up of seven fragments. This object was thus restored before being studied. In spite of the fragmentation, the state of the surfaces is very good and allows for an accurate interpretation of the technical traces and the drawings on this object. It is a right reindeer metatarsal with a posterior trough with traces of grooving (fig. 2). It is thus an "emergent" matrix for which the debitage process was interrupted.

The lateral surface bears a very clear decoration of nested chevrons (fig. 2). Three of them are whole but dissymmetrical with a short side whereas the other is longer and curved, and concave towards the inside. The pattern and the layout are very clear but the two lines of each chevron do not intersect, and a space of several millimetres systematically replaces the apex. Two curved lines complete the pattern by forming two half-chevrons.

9 These chevrons cover a lot of the available surface and are thus unusually large compared to the other graphic depictions from Bourrouilla. It is not possible to establish a chronology concerning the engraving and the use of the object as a matrix.

\section{3 -Hyoid bone engraved with an interlocking chevron pattern (ARA14 L18 R-307)}

Dim.: 85 × 17 × $4 \mathrm{~mm}$

This piece was discovered in five fragments and was restored before study. It is a branch of a hyoid bone, probably from a horse, with two surfaces engraved with nonfigurative patterns (fig. 3). The convex surface is decorated with oblique lines. They are more or less parallel and regularly spaced, and are all aligned along the same edge of the piece and interrupted several millimetres from the opposite edge.

11 The plane surface bears a more complex pattern. Multiple lines run across the axis of the piece, which is divided into equal-sized decorated parts. The half of the length of the fragment in our possession bears oblique lines converging on the median line forming interlocking chevrons. On the other half, oblique lines only cover one side of the surface, and then a new series of interlocking chevrons appears in the opposite direction to the first. This second series is quickly interrupted by the break. Overall, two groups of chevrons and fishbone patterns seem to be opposite each other at each end of the object. 


\section{4 - Fragment of a decorated needle (ARA14 - M17 S1 370-372)}

Dim.: $8.3 \times 2.1 \times 0.8 \mathrm{~mm}$

This small proximo-mesial needle fragment was found in a sieve residue (fig. 4) and is part of a series of small-sized needles, often with flattened cross-sections, discovered in US 2007 at Bourrouilla. In spite of the proximal break, part of the needle hole is still present, and was clearly obtained by bifacial perforation. At the distal end, one of the surfaces bears traces of a break caused by bending.

Both sides of this needle bear an interlocking chevron decoration. There are five on one side and three on the other. This is the first decorated needle discovered at Arancou. There are few examples of this type of object in the literature and decoration is often limited to transverse incisions. We can cite the example of objects from La Vache (Chauvière 2003), Duruthy (Dachary et al. 2006) or Furtins Cave (Stordeur-Yedid 1979). Besides the limited surface available for engraving, this graphic paucity can be explained by the fact that any irregularities in the surface of the needle lead to a loss of efficacy (Stordeur-Yedid 1979).

Given this context, the specimen from Bourrouilla represents an exceptional find.

Figure 2 - ARA14 R2014-304. Reindeer metatarsal with engraved interlocking chevron pattern. The posterior trough and the decorated surface bear marks comparable to attempted grooving (Photo $\mathrm{F}$. Plassard).

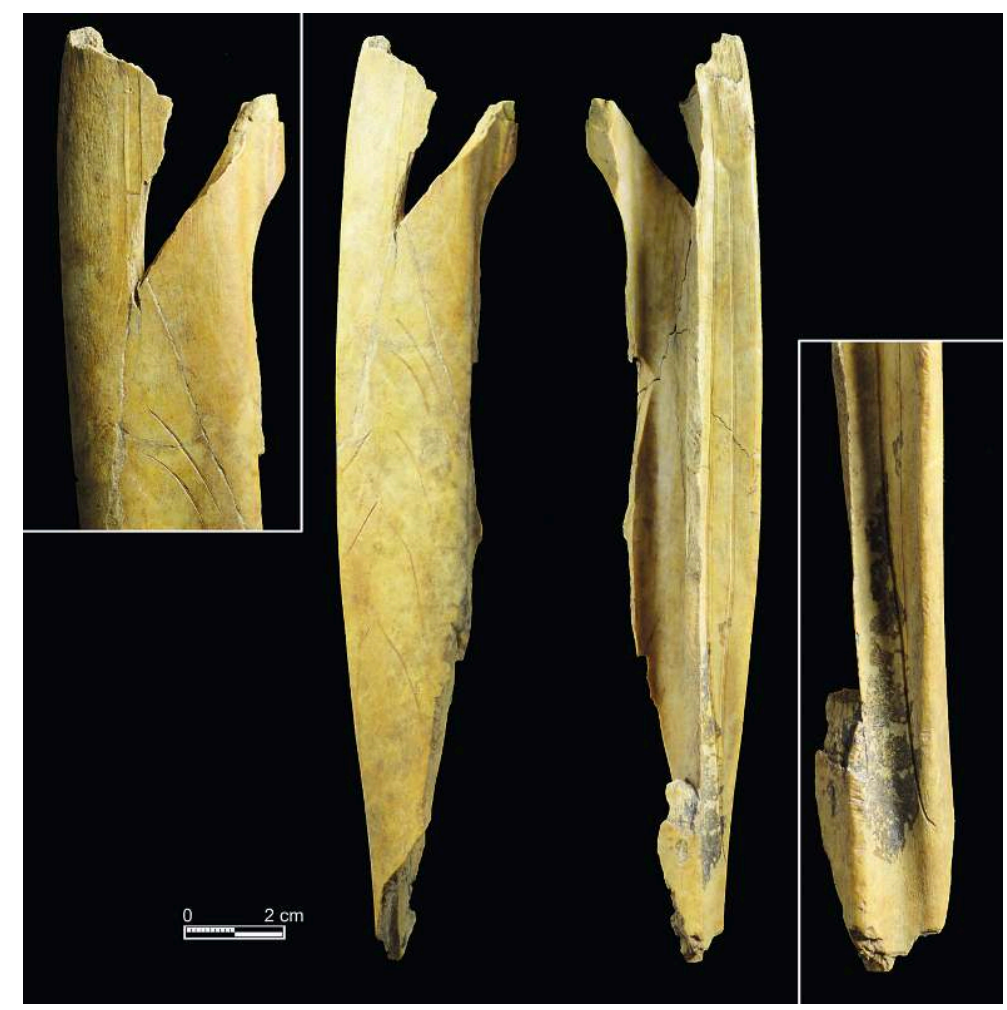


Figure 3 - ARA14 L18 R-307. Hyoid with engraved interlocking chevron pattern (Photo F. Plassard. Record Lise Aurière).
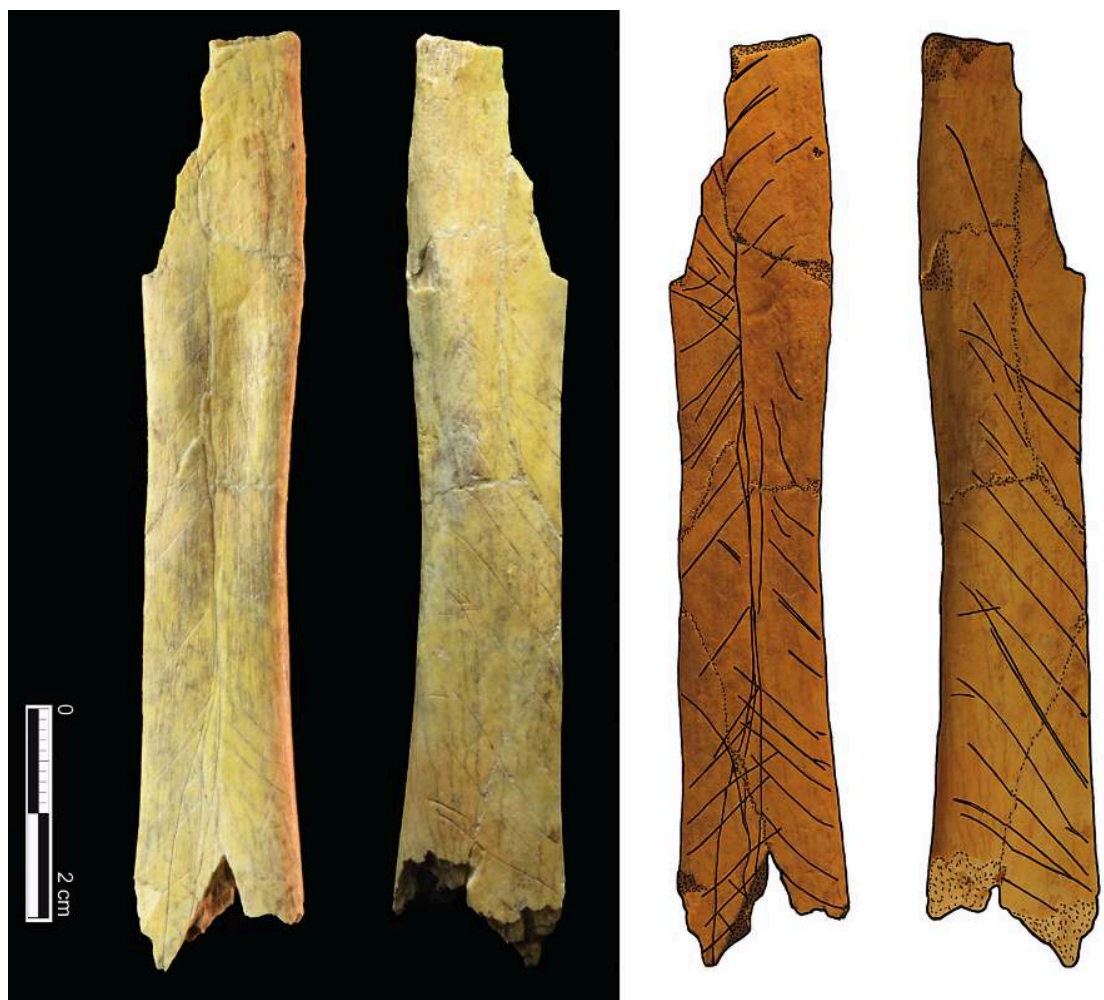

Figure 4 - ARA14 M17 S1 370-372. Proximal needle fragment decorated with an interlocking chevron pattern (Photo F. Plassard).

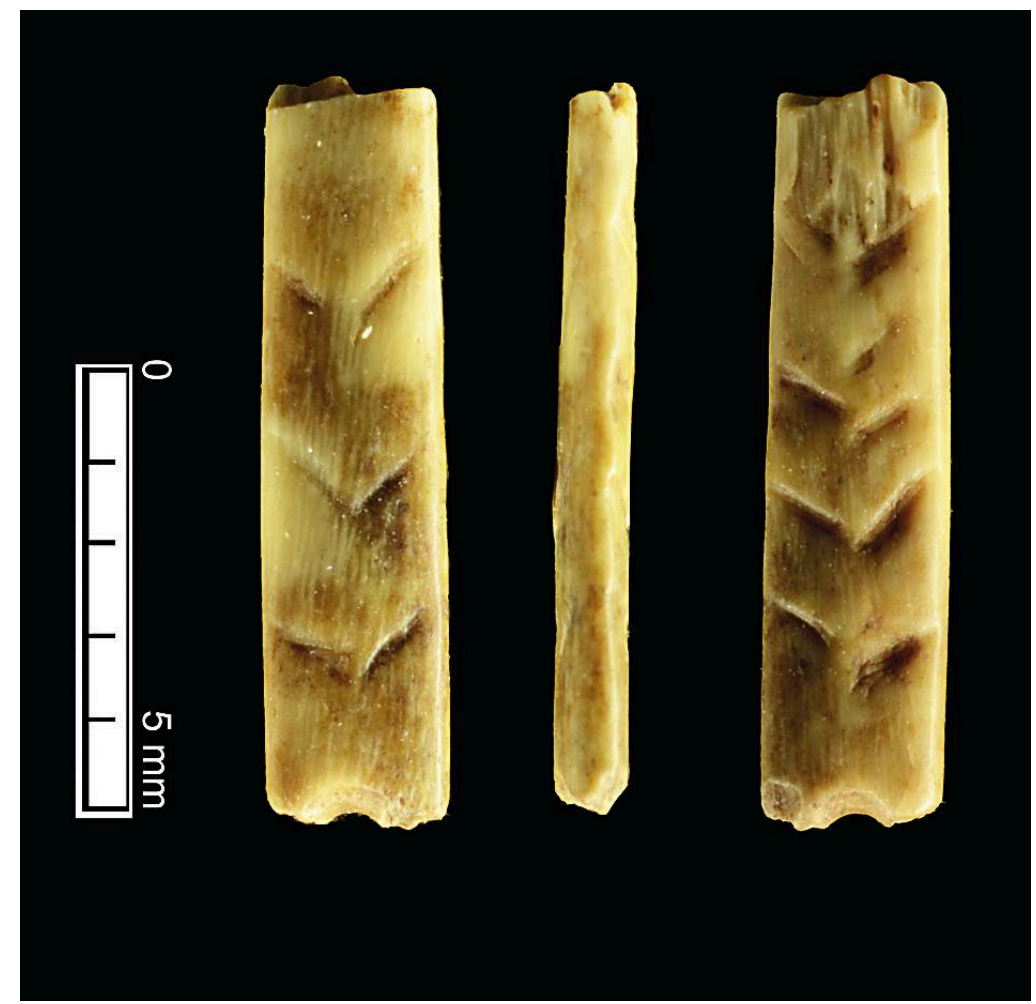




\section{5 - Fragment of a decorated sacrum (ARA14 L17 4974)}

Dim.: $63 \times 33 \times 15 \mathrm{~mm}$ part of the vertebral arch and the spinous process. Only one anatomic edge corresponding to the vertebral arch subsists. The rest of the contour of the object is made up of breaks (fig. 5).

16

of the fractured edges bear discreet traces of tools, perhaps linked to regularizing the contour of the object. The engravings were made after the breaks and are mostly concentrated on the left part of the fragment (vertebral arch). The opposite surface does not bear any marks, but is divided into two equal parts by a break corresponding to the elimination of the second part of the vertebral arch.

17 Although the engravings appear to be organized, it is difficult to describe them. Technically, two types of lines exist: three rather deep lines on one hand and more numerous, more superficial marks on the other. The most marked lines are two curved and parallel lines visible at the top and the bottom of the fragment and clearly obtained by the repetitive movement of the tool. They run from the anatomic edge (upper left) and are interrupted on the opposite edge (lower left edge). The third line of this type is shorter, rectilinear and located beside the lower part of the right edge of the object. The other engravings follow two main directions. Six vertical lines are spread over the left third of the blank. The first three, in the upper left angle, are close to each other. Further to the right, two lines form a first line from the upper edge to several millimetres from the lower left edge. One centimetre further to the right, a series of lines outline another line parallel to the previous line. The lower part of this line is accompanied by short parallel cross-hatched lines.

Figure 5 - ARA14 L17 4974. Engraved bovine sacrum fragment. Indeterminate pattern (Photo F Plassard. Record Lise Aurière).
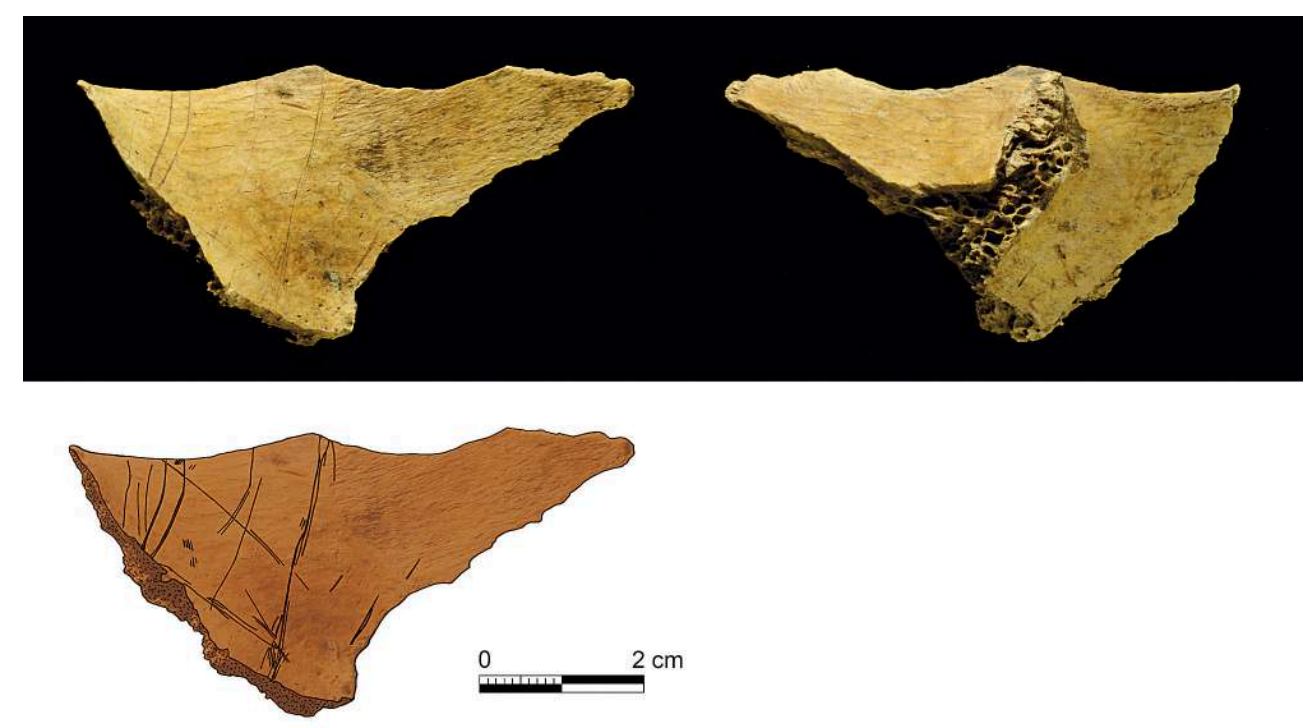

18 Two large lines run in a different direction, more or less parallel to the lower left edge. The first part begins on the upper left edge and is interrupted at the intersection with the vertical line furthest to the right whereas the second is tangential to the lower left edge and ends at the end of the same vertical line on the right. Lastly, several short 
cross-hatched lines are spread over the decorated area. The overall impression is of a grid with a diamond-shaped mesh. However, the interpretation of the pattern remains difficult.

\section{6 - Bison in frontal view (ARA14 R2014-303)}

Dim.: 76 x 16 x $7 \mathrm{~mm}$

This remain is a distal fragment of a left red deer ulna (fig. 6), with engravings on the medial surface. It was discovered in three fragments beside a hearth zone and was restored before being studied. Nonetheless, the decorated surface presents several lacunae. The whole engraved surface bears fine parallel and regular scraping marks which undoubtedly correspond to the preparation of the blank.

The decoration is made up of two graphic units placed one above the other when the piece is held vertically. At the top (the proximal part), we can see an animal head in front view. It measures $21 \mathrm{~mm}$ high. The horns, frontal toupet, an eye, an ear and the contour of the muzzle are clearly visible. The muzzle is depicted by two secant curves, forming an angular snout. Only the left ear is visible and it is proportionally too large in relation to the rest of the figure. Both horns are indicated but they are not perfectly symmetrical. The right eye is "awkwardly" drawn in the middle of two bracket lines, one of which is much too long and goes beyond the head outline. Four short crosshatched lines on the left of the head could be the beginning of the neckline. On account of the shape of the horns, the position of the ear and the presence of a frontal toupet, we interpret this animal as a bison.

Non-figurative lines are visible below the bison (distal part of the blank). We can distinguish three longitudinal lines running from the conserved end of the blank and a series of oblique transverse lines and more or less parallel lines unequally spread over the whole available surface.

Large herbivores are not often depicted in frontal view in Upper Palaeolithic art. This object is the first example of this discovered so far in the iconography of Bourrouilla. However, this theme is part of parietal and portable art. We can cite Magdalenian examples from La Madeleine, La Vache and Gourdan (Paillet 1996; Baffier et al. 2003; Tymula 1991). In the latter site, two objects present engraved bisons in front view. One of them is an antler fragment associated with very succinct figuration (horns, frontal toupet and ear) and an undulating line similar to the non-figurative pattern described here (Tymula, op. cit, fiche 46). 
Figure 6 - ARA14 R2014-303. Deer ulna with an engraved bison in frontal view (Photo F. Plassard. Record Lise Aurière).
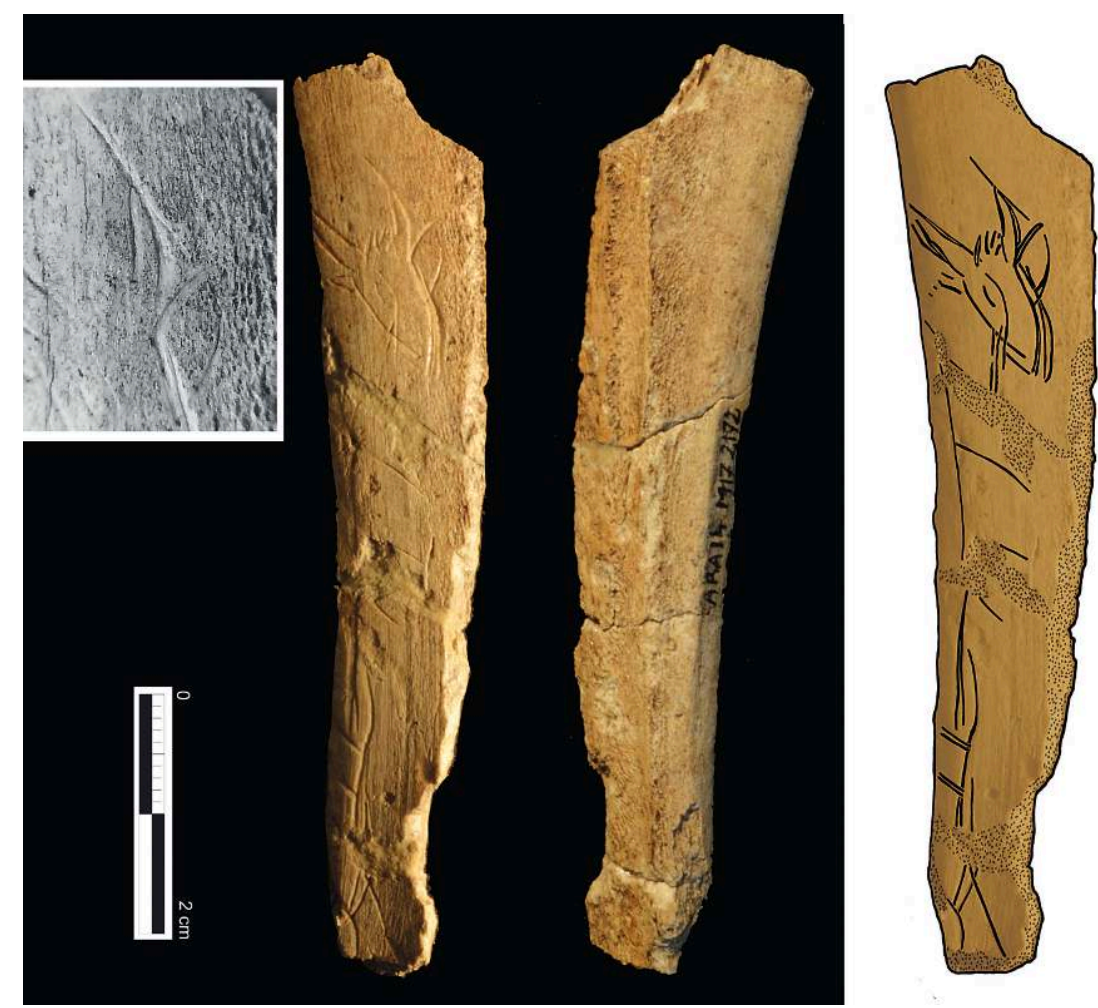

\section{7 - Reindeer hemi-mandible (ARA14 L18 1023)}

Dim.: 64 × $39 \times 11 \mathrm{~mm}$

This is a fragment of a right reindeer hemi-mandible with the second premolar (fig. 7). The vestibular surface bears a natural foramen situated slightly in front of the P2 and another at the distal end of the piece that may have been made.

The piece is fractured at the back of the P1 along a sub-orthogonal line on the lower edge. On the vestibular surface, the fractured side bears traces of tearing away, or percussion, whereas the edge is clear-cut on the lingual surface.

There are several oblique incisions on the lower part of the vestibular surface and very faint striations on the lingual surface. On the distal part, the fracture of the object is also very clear and orthogonal compared to the axis of the object. The vestibular surface is indented over a surface of about $6 \mathrm{~mm}$ tall and $5 \mathrm{~mm}$ deep and appears to correspond to the working of a natural foramen.

The interpretation of this object is difficult as the observable striations are not very marked and could only result from quartering or defleshing. In addition, the breaks are slightly blunted and thus not very easy to interpret. However, given the overall morphology, this object appears to be an animal head, where the tooth represents the ear, the natural foramen the eye and the distal indentation the nostril. Although it is difficult to confirm the deliberate anthropogenic origin of this shape, it seems legitimate to advance the hypothesis that it is an unusual contour découpé. This category of objects was not known at Bourrouilla up until now. 


\section{8 - Fragment of a half-round decorated rod (ARA14 N16 91)}

Dim.: $62 \times 10 \times 3 \mathrm{~mm}$

This is a mesial fragment of a half-round rod (fig. 8) discovered in US 2010. The lower surface is very regularized, concave and bears oblique parallel rectilinear incisions. The latter were intended to stick the object onto a similar volume (Feruglio 1992; Rigaud $2006,2013)$. One of the ends of the fragment in our possession bears a decoration consisting of two lateral patterns. They are identical on both sides and are made up of a series of short cross-hatched lines $(2 \mathrm{~mm})$, which are delimited at the top by a rectilinear or slightly curved line.

The discovery of a fragment of a half-round rod in cervid antler is important for the chronology of the occupations in the cave. This discovery provides the basis for a reasoned stratigraphic discussion of the presence of the middle Magdalenian phase in Arancou Cave.

\section{9 - Review}

Excavations at Bourrouilla are still ongoing and we hope that they will uncover further objects to add to the portable art corpus. The following observations are thus just an updated overview as the objects presented here complete the already available data (Fritz and Roussot in Chauchat et al. 1999; Aurière et al. 2013). They enable us to confirm some observations and to revise others.

Figure 7 - ARA14 L18 1023. Reindeer hemi-mandible fragment (Photo F. Plassard).

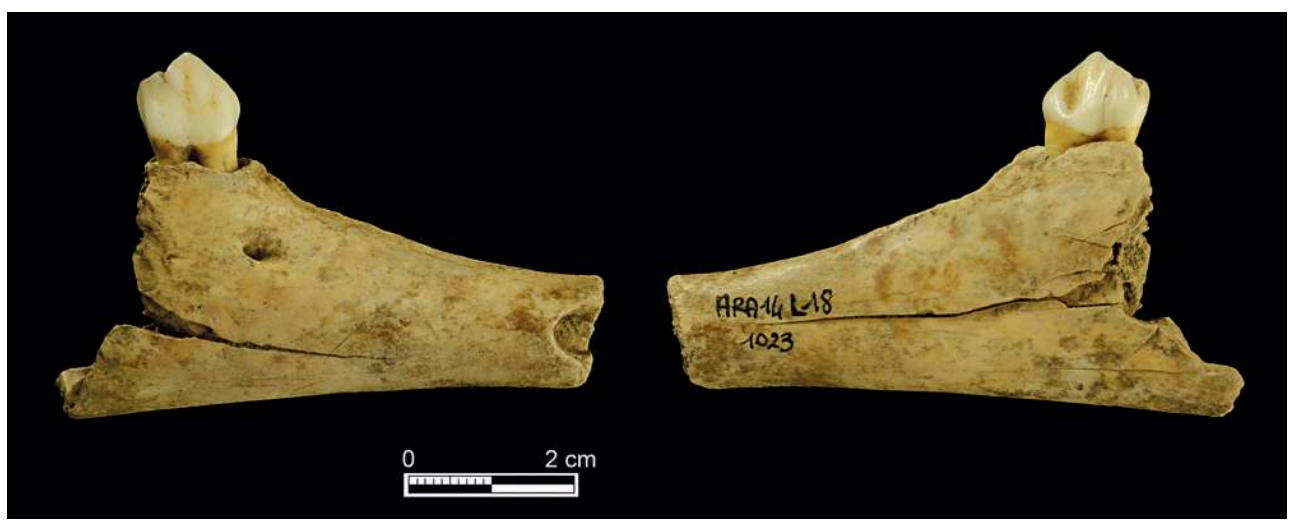


Figure 8 - ARA14 N16 91. Decorated half-round rod (Photo F. Plassard).

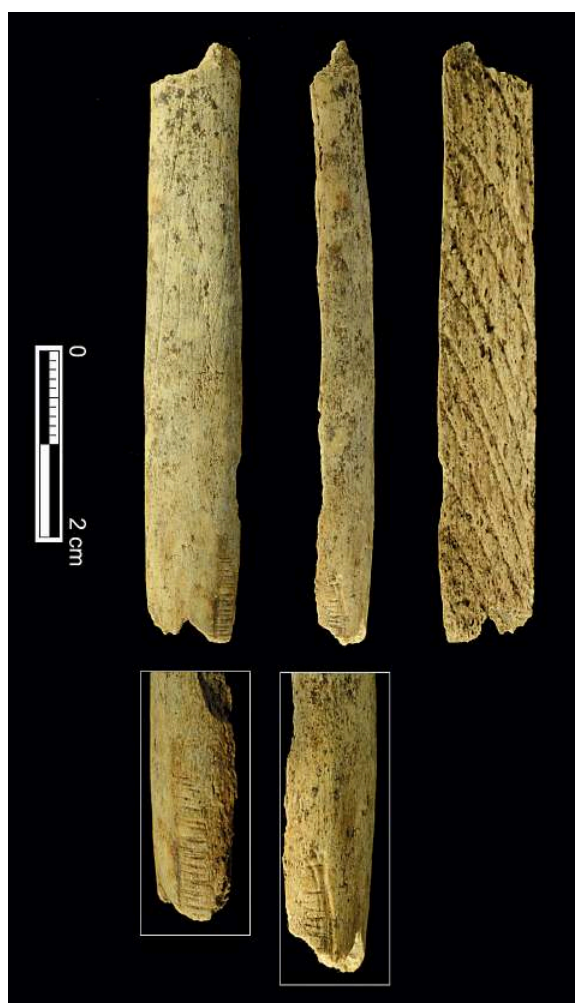

First of all, we can confirm that none of the decorated pieces attributed to the Upper Magdalenian are in reindeer or deer antler. The only decorated material is bone whereas the only piece assigned to the Middle Magdalenian or to the transition between the Middle and Upper Magdalenian is a half-round rod in deer antler. However, the bone blanks provide evidence of clear diversification. Up until now ribs were the preferred bone blank and the only exceptions to this were bird bones and a deer tibia bone shaft. At the present time, the corpus has been enriched by a hyoid horse bone, a reindeer metatarsal, a deer ulna and a fragment of a sacrum from a large bovine. These two latter blanks are not generally used. Then, there is also the question of the possibly worked reindeer mandible.

The clandestine excavation inside the cavity gives the false impression of a very standardized portable art production on ribs or half-ribs made into lissoirs or pendants. With the recent excavations, the increased diversity of blanks from a specific and anatomic viewpoint is combined with "functional" diversity. Therefore, in the Upper Magdalenian from Bourrouilla, blanks presenting very little modification coexist with a matrix and finished objects.

Iconic diversification accompanies blank diversification, such as the use of the frontal view (of a bison), which had only been mentioned up until now for possible bird depictions (Eastham 1988 and pers. com.). In the same way, we observe the importance of an unprecedented geometric pattern at Arancou: interlocking chevrons. Generally speaking, although non-figurative engraved pieces are relatively frequent (on different blanks), clearly organized geometric patterns are discreet. A grid on a rib described by Fritz and Roussot (in Chauchat et al. 1999), a pendant decorated with triangles (Aurière et al. 2013), or an ochre stick engraved with a zigzag form (Fritz and Roussot in 
Chauchat et al. 1999) are some of the rare examples of a corpus made up of 29 animal figurations on about twenty blanks.

The discovery of a decorated needle also confirms the technical skills of some engravers, who were capable of decorating a surface of several square millimetres. As suggested earlier (Aurière et al. 2013), engravers with different levels of skills seemed to coexist. Although the decoration is relatively simple, the decorated needle illustrates perfect control of engraving in spite of the very limited size of the blank and the decoration. In parallel, the bison head in frontal view demonstrates the difficulties involved in holding the tool and carrying out precise gestures. The eye, the left ear, and the right horn are the best evidence of this (fig.6, thumbnail).

Perhaps the different dimensions of the engravings are another indicator of variable skill levels. This idea has already been advanced (Aurière et al. 2013), and is perhaps confirmed by the discovery of the same pattern of interlocking chevrons on what is now the largest decorated blank in Bourrouilla - the reindeer metatarsal - and on what is undoubtedly the smallest image - the engraved needle.

Lastly, the discovery of a half-round decorated rod in stratigraphic context is a noteworthy element. Apart from the intrinsic importance of this object, it is the first element in primary position pointing to the presence of the middle phase of the Magdalenian in Arancou Cave. Up until now, the exploratory survey carried out in front of the entrance has reached a level containing two bifurcated spear point bases. In addition, the clandestine excavation spoil heap yielded four spear heads of the same type, as well as fragments of half-round Isturitz-type rods decorated with tuberosities. However, the attribution of these remains to the Middle Magdalenian and/or an early phase of the Ipper Magdalenian is still subject to debate at Arancou (Bonnissent and Chauvière in Chauchat et al. 1999 - p. 51) and on a wider scale (Pétillon 2007).

The continuation of excavations will complete the corpus of remains from the Upper Magdalenian from US 2007 and will provide the opportunity to characterize earlier occupations associated with US 2010.

\section{BIBLIOGRAPHIE}

AURIÈRE L., CHAUVIÈRE F.-X., PLASSARD F., FRITZ C., DACHARY M. 2013 - Art mobilier inédit du gisement de Bourrouilla à Arancou (Pyrénées-Atlantiques, France) : données techno-stylistiques et chrono-culturelles. Paleo, p. 195 - 218.

BAFFIER D., BUISSON D., DELPORTE H., FRITZ C., GUY E., KANDEL D., MONS L., SIMONNET R., TOSELLO G., WELTE A.-C. 2003 - Lissoirs. In : J. Clottes et H. Delporte (Dir.), La grotte de La Vache (Ariège). Fouilles Romain Robert. II- L'art mobilier, Paris, Coédition CTHS-RMN, vol. 2, p. 279-319.

CHAUCHAT Cl. (dir.), FONTUGNE M., HATTE C., DACHARY M. BONNISSENT D., CHAUVIÈRE F.-X., ROUSSOT A., FRITZ C., FOSSE Ph., EASTHAM A., MARTIN H., LE GALL O., GAMBIER D. 1999 L'habitat Magdalénien de la grotte Bourrouilla à Arancou (Pyrénées Atlantiques). Gallia Préhistoire, 41, p. 1-151. 
CHAUVIÈRE F.-X. 2003 - Aiguilles. In : J. Clottes et H. Delporte (Dir.), La grotte de La Vache (Ariège). Fouilles Romain Robert. II- L'art mobilier, Paris, Coédition CTHS-RMN, vol. 2, p. 320-323.

DACHARY M. (dir.), CHAUVIÈRE F.-X., COSTAMAGNO S., DAULNY L., GAMBIER D. LAROULANDIE V. 2006 - «Les Magdaléniens à Duruthy », catalogue d'exposition (7 octobre-10 décembre 2006), Hastingues, Centre Départemental du Patrimoine, 188 p.

DACHARY M., PLASSARD F., CHAUVIÈRE F.-X., AURIÈRE L., FRITZ C. sous presse - Le contexte des œuvres d'art mobilier dans le Magdalénien supérieur de la grotte Bourrouilla (Arancou, Pyrénées-Atlantiques, France). Actes du colloque « L'art au quotidien. Objets ornés du Paléolithique supérieur » Les Eyzies-de-Tayac du 16 au 20 juin 2014. Paleo.

EASTHAM A. 1988 - The season or the symbol: the evidence of swalloxs in the Palaeolithic of Western Europe. Archaeozoologia, II(1-2), p. 243-252.

FERUGLIO V. 1992 - Fiche « Baguettes demi-rondes » In: Camps-Fabrer H. (Ed.), Fiches typologiques de l'industrie osseuse préhistorique. Cahier 5 : bâtons percés, baguettes, Aix-en-Provence, Université de Provence, (Commission de la nomenclature sur l'industrie de l'os préhistorique) p. 71-83.

PAILLET P. 1996 - A propos de trois bisons magdaléniens exceptionnels (La Madeleine, Dordogne), Paleo, 8, p. 359-369.

PÉTILLON J.-M. 2007 - Les pointes à base fourchue de la zone pyrénéo-cantabrique : un objet à la charnière entre Magdalénien moyen et Magdalénien supérieur? In : Frontières naturelles et frontières culturelles dans les Pyrénées préhistoriques, N. Cazals, J. González Urquijo, X. Terradas (dir.), Santander, Ediciones de la Universidad de Cantabria, p. 245-264.

RIGAUD A. 2006 - Étude technologique des baguettes demi-rondes de Labastide (Hautes-Pyrénées). Archéologie des Pyrénées occidentales et des Landes, 25, p. 229-246.

RIGAUD A. 2013 - Voir les baguettes demi-rondes avec le regard d'un menuisier, In : de Beaune S. A. (dir.), Chasseurs-cueilleurs. Comment vivaient nos ancêtres du Paléolithique supérieur. Méthodes d'analyse et d'interprétation en préhistoire, Paris, CNRS Editions (1ère édition 2007), p. 69-77.

STORDEUR-YEDID D. 1979 - Les aiguilles à chas au Paléolithique. XIIIº supplément à Gallia Préhistoire. Paris, CNRS Editions. 215 p.

TYMULA S. 1991 Animaux et Humains en vue frontale. Étude des représentations mobilières et pariétales pyrénéennes. Maîtrise de Préhistoire. Université de Paris I., 2 vol. , 426 p.

\section{RÉSUMÉS}

Lors de la campagne de fouille de 2014 dans la grotte de Bourrouilla à Arancou (PyrénéesAtlantiques), huit nouvelles pièces ornées ont été découvertes dans les niveaux magdaléniens. Ces objets trouvés en contexte stratigraphique confortent l'importance de la production d'art mobilier au sein du gisement. Si la majorité d'entre eux est clairement associée au Magdalénien supérieur, une baguette demi-ronde pourrait documenter une occupation plus ancienne et nourrit le débat sur la transition entre Magdalénien moyen et supérieur. La présente note a pour but de décrire ces objets et d'établir un premier bilan fondé sur des comparaisons avec les pièces précédemment découvertes.

During the excavation campaign in 2014 at Bourrouilla cave (Pyrénées-Atlantiques), eight new decorated objects were discovered in the magdalenian layers. These remains, from well preserved layers, confirm the importance of the artistic production in this site. If the majority of these objects are certainly attributed to the upper Magdalenian, one of these is a decorated half- 
round rod which give new data about the transition between the middle Magdalenian and the upper Magdalenian. This short paper presents these pieces and takes stock based on comparisons with the remains found before.

\section{INDEX}

Keywords : Bourrouilla, Pyrénées-Atlantiques, Magdalenian, Mobile art, Bone industry

Mots-clés : Bourrouilla, Pyrénées-Atlantiques, Magdalénien, art mobilier, industrie osseuse

\section{AUTEURS}

\section{FRÉDÉRIC PLASSARD}

Université Bordeaux 1, UMR 5199, PACEA, Allée Geoffroy Saint-Hilaire, CS 50023 - 33615 Pessac Cedex - frederic.plassard@wanadoo.fr

\section{LISE AURIÈRE}

Université Toulouse-Jean Jaurès, UMR 5608, TRACES, Maison de la recherche, 5 allée Antonio Machado, FR-31058 Toulouse cedex - lise.auriere@gmail.com

\section{FRANÇOIS-XAVIER CHAUVIÈRE}

Office du patrimoine et de l'archéologie de Neuchâtel - section Archéologie, Laténium, CH-2068 Hauterive - francois-xavier.chauviere@ne.ch

\section{CAROLE FRITZ}

Université Toulouse-Jean Jaurès, UMR 5608, TRACES, Maison de la recherche, 5 allée Antonio Machado, FR-31058 Toulouse cedex - carole.fritz@univ-tlse2.fr

\section{MORGANE DACHARY}

Université Toulouse-Jean Jaurès, UMR 5608, TRACES, Maison de la recherche, 5 allée Antonio Machado, FR-31058 Toulouse cedex - morgane.dachary@orange.fr 